\title{
Comparison of venous plasma glycemia and capillary glycemia for the screening of type 2 diabetes mellitus in the Japanese-Brazilian community of Mombuca (Guatapará-SP)
}

Maria Cristina Foss-Freitas ${ }^{1 *}$, Regina CG de Andrade ${ }^{2}$, Roberta C Figueiredo ${ }^{3}$, Ana Emília Pace ${ }^{4}$, Edson Z Martinez ${ }^{3}$, Amaury L Dal Fabro ${ }^{3}$, Laércio J Franco ${ }^{3}$, Milton C Foss ${ }^{1}$

\begin{abstract}
Background: To identify the most appropriate cut-off points of fasting glycemia for the screening of diabetes mellitus type 2 (DM2) with the comparison of the properties of capillary glycemia (CG) and venous blood plasma glycemia (PG) in a population of Japanese origin from the community of Mombuca, Guatapará - SP, Brazil.

Methods: This was a population-based descriptive cross-sectional study conducted on a sample of 131 individuals of both genders aged 20 years or more (66.8\% of the target population). CG was measured with a glucometer in a blood sample obtained from the fingertip and PG was determined by an enzymatic method (hexokinase) in venous blood plasma, after a 10-14 hour fast in both cases. Data were analyzed by the receiver operating characteristic (ROC) curve in order to identify the best cut-off point for fasting glycemia (CG and PG) for the diagnosis of DM, using the 2-hour plasma glycemia > $200 \mathrm{mg} / \mathrm{dl}$ as gold - standard.

Results: The ROC curve revealed that the best cut-off point for the screening of DM was $110 \mathrm{mg} / \mathrm{dl}$ for CG and $105 \mathrm{mg} / \mathrm{dl}$ for $P G$, values that would optimize the relation between individuals with positive and false-positive results. The area under the ROC curve was 0.814 for CG $(p<0.01)$ and 0.836 for $P G(p<0.01)$.

Conclusions: The cut-off points of $105 \mathrm{mg} / \mathrm{dl}(5.8 \mathrm{mmol} / \mathrm{l})$ for PG and of $110 \mathrm{mg} / \mathrm{dl}(6.1 \mathrm{mmol} / \mathrm{l})$ for CG appear to be the most appropriate for the screening of DM2 in the population under study, with emphasis on the fact that the value recommended for $\mathrm{CG}$ is $5 \mathrm{mg} / \mathrm{dl}$ higher than that for $\mathrm{PG}$, in contrast to $\mathrm{WHO}$ recommendations.
\end{abstract}

\section{Background}

Diabetes mellitus type 2 (DM2) is a highly prevalent disease of epidemic projection for the next few years both in developed and developing countries [1], representing an important public health problem in view of the high morbidity and mortality of the disease itself and the high costs involved in its control and in the treatment of its complications. DM2 is among the 10 major causes of death in several industrialized and emergent countries [2,3]. In 2002, the cost of treating diabetic patients in the US was more than double the cost of treating non-

\footnotetext{
* Correspondence: crisfoss@fmrp.usp.br

'Departamento de Clinica Médica, Faculdade de Medicina de Ribeirão PretoUSP, (Av. Bandeirantes 3900), Ribeirão Preto-SP(14049-900), Brazil
}

diabetic individuals, amounting to approximately US $\$ 132$ billion [4].

Over the last few years, a worldwide trend has been observed showing that migrant populations present a pattern of morbidity-mortality that differs from that of the community of origin of their parents, but follows the disease profile of local residents. Epidemiological studies have demonstrated changes in the prevalence of non-transmissible chronic diseases, DM2 in particular, among Japanese migrants and their descendants. In this respect, higher prevalences of DM2 (16-20\%) have been observed among Japanese residing in the US than among Japanese residing in Japan (4-5\%) [5,6]. Similarly, a high prevalence of DM2 [7,8] (36.2\%) and of impaired glucose tolerance $(\mathrm{IGT}=23.4 \%)$ have been detected 
among Japanese individuals living in Brazil, corresponding to higher values than those detected in the Brazilian population [9]. These changes are explained by modifications of life style, with the incorporation of new cultural patterns and changes in eating habits. However, other factors also participate in this process, such as greater population longevity, miscegenation and the sociodemographic transformation due to urbanization and economic development [10].

Despite the proven benefit of early detection of the disease [11], universal screening for DM2 has been questioned [12]. The most accepted recommendation is the screening of asymptomatic individuals with a greater risk for the disease [13-15], using the determination of fasting plasma glucose level as the worldwide accepted method for screening and diagnosis. On the other hand, in view of its practical application, agility, rapidity and safety, the capillary glycemia (CG) test is an important option for the screening of DM in detection campaigns or in population studies [16].

The objective of the present population-based study was to identify the best cut-off points of fasting glycemia for the screening of DM2 and to compare the properties of fasting capillary glycemia (CG) and fasting venous plasma glycemia (PG) by the analysis of the areas under the receiver operating characteristic (ROC) curve [17] in a population of Japanese origin living in the community of Mombuca, Guatapará - SP, Brazil.

\section{Methods}

The data were obtained in a cross-sectional descriptive study conducted on the Japanese-Brazilian population of Mombuca, Guatapará - SP, during the period from April to December 2005. Among $1^{\text {st }}$ and $2^{\text {nd }}$ generation individuals (Issei and Nissei, respectively) of both genders and older than 20 years, 131 (66.8\% of the population in this age range) agreed to participate in the study. The study was approved by the Research Ethics Committee of the Health Teaching Center of the Faculty of Medicine of Ribeirão Preto-USP, under protocol n ${ }^{\circ} 104 /$ 03 and all subjects gave written informed consent to participate.

On a scheduled date, each participant came to the office of the Agricultural and Sports Association of Guatapará for information about the study. After a fasting period of 10 to 14 hours, a venous blood sample was obtained from each subject for PG determination and a blood sample was obtained from a fingertip for the determination of CG. The blood samples were collected into vacuum tubes containing sodium fluoride and used for PG determination by enzymatic method (hexokinase) with a Cobas Mira Plus Analyser. CG was measured with a glucometer (Advantage-Roche) and reported as whole blood glucose level. Individuals presenting CG of less than $200 \mathrm{mg} / \mathrm{dl}$ were then asked to perform the 75 g glucose tolerance test, excluding those with previously diagnosed diabetes.

Subjects were considered to have diabetes mellitus when their fasting glycemia was $\geq 126 \mathrm{mg} / \mathrm{dl}(7.0 \mathrm{mmol} /$ l) or when their glycemia was $\geq 200 \mathrm{mg} / \mathrm{dl}(11.1 \mathrm{mmol} / \mathrm{l})$ 2 hours after $75 \mathrm{~g}$ glucose load, or if they were under treatment for diabetes. Subjects were considered to be pre-diabetic when their fasting glycemia was $110(6.1$ $\mathrm{mmol} / \mathrm{l}$ ) to $126 \mathrm{mg} / \mathrm{dl}$ (impaired fasting glycemia) and/ or when their glycemia was $140(7.8 \mathrm{mmol} / \mathrm{l})$ to $200 \mathrm{mg} /$ dl 2 hours after glucose overload (impaired glucose tolerance). This diagnostic criteria for diabetes or pre-diabetes was based on plasma glucose levels [16].

\section{Statistical Analysis}

CG and PG data were compared between the diabetic and non-diabetic groups by the Student $t$-test for independent samples, with the level of significance set at $\mathrm{p}<$ 0.05. CG and PG were compared in terms of sensitivity and specificity using the ROC curve, considering the diagnostic standard for diabetes mellitus to be PG $\geq 200$ $\mathrm{mg} / \mathrm{dl}(11.1 \mathrm{mmol} / \mathrm{l}) 2$ hours after the ingestion of $75 \mathrm{~g}$ anhydrous glucose. The criterion used to select the cutoff points of the fasting glycemias (CG and PG) was based on the values with the closest sensitivity and specificity. The areas under the ROC curve for fasting PG and CG were compared by the nonparametric test proposed by DeLong et al. [18]. For interpretation of the results, it is considered that the greater the area under the ROC curve, the greater the discriminant power of the test for a determined outcome.

\section{Results}

The clinical data of the participants are presented on Table 1. Among the 131 individuals evaluated, five were excluded because they were previously diagnosed diabetics and nine did not perform the CG test. Among the subjects without DM, mean CG was significantly higher (8\%) than PG, whereas among subjects with DM the differences were nonsignificant, although mean CG was 5\% higher than PG (Table 2). The prevalence of DM and IGT in this group were $13.7 \%$ and $14.5 \%$, respectively, and the frequency of hypertension (>140/90 $\mathrm{mmHg}$ ) was $48.1 \%$.

Table 1 Clinical data of the Japanese-Brazilian population of Mombuca, Guatapará-SP, 2005 (Mean \pm SD).

\begin{tabular}{lccc}
\hline & $\begin{array}{c}\text { Total } \\
(\mathbf{N}=\mathbf{1 3 1})\end{array}$ & $\begin{array}{c}\text { Men } \\
(\mathbf{N}=\mathbf{5 4})\end{array}$ & $\begin{array}{c}\text { Women } \\
(\mathbf{N}=\mathbf{7 7})\end{array}$ \\
\hline Age (years) & $56.7 \pm 15.9$ & $55.1 \pm 15.9$ & $57.8 \pm 16.1$ \\
Body Weight $(\mathrm{Kg})$ & $61.7 \pm 14.3$ & $70.6 \pm 14.5$ & $55.2 \pm 10.2$ \\
Height $(\mathrm{m})$ & $1.6 \pm 0.1$ & $1.7 \pm 0.1$ & $1.5 \pm 0.1$ \\
BMl $\left(\mathrm{kg} / \mathrm{m}^{2}\right)$ & $24.7 \pm 4.0$ & $25.4 \pm 4.2$ & $24.1 \pm 3.9$ \\
Waist Circumference $(\mathrm{cm})$ & $84.9 \pm 10.6$ & $88.6 \pm 10.1$ & $83.1 \pm 10.7$
\end{tabular}


Table 2 Fasting CG and PG levels of the Japanese-Brazilian population of Mombuca, Guatapará-SP, 2005 (Mean \pm SD).

\begin{tabular}{lccc}
\hline GLYCEMIA & Normoglycemic + IGT & DM & $p$-value* \\
\hline CG $(\mathrm{mg} / \mathrm{dl})(\mathrm{N}=117)$ & $95.9 \pm 15.8$ & $120.5 \pm 19.1$ & $<0.0001$ \\
$\mathrm{PG}(\mathrm{mg} / \mathrm{dl})(\mathrm{N}=126)$ & $88.4 \pm 8.9$ & $113.8 \pm 20.1$ & $<0.0001$ \\
-value* $^{*}$ & $<0.0001$ & 0.4140 & \\
\hline
\end{tabular}

* Student t-test

The ROC curve revealed that the ideal cut-off point for DM screening was $105 \mathrm{mg} / \mathrm{dl}$ for PG and $110 \mathrm{mg} / \mathrm{dl}$ for CG (Fig. 1), values that would optimize the relation between subjects with positive and false-positive results. The level of $110 \mathrm{mg} / \mathrm{dL}$ in CG showed $77.8 \%$ sensitivity and $82 . \%$ specificity and the level of $105 \mathrm{mg} / \mathrm{dL}$ in PG showed $72.7 \%$ sensitivity and $93.0 \%$ specificity. It can be seen that PG showed a better power for the detection of $\mathrm{DM}$, with a greater area under the ROC curve $(0.836$ $\mathrm{p}<0.01)$ compared to CG $(0.814-\mathrm{p}<0.01)$, although the difference was nonsignificant $(\mathrm{p}=0.66)$.

\section{Discussion}

The high prevalence of DM and the epidemic projections of the disease for the next few years in both developed and developing countries are a source of concern for the health area authorities. In addition, the fact that 35 to $50 \%$ of the individuals with DM do not know that they have the disease and that at the time of diagnosis the patients already present micro- and macrovascular complications, supports the importance of establishing an early diagnosis of DM, which would prevent the occurrence of many of these complications $[19,20]$.

The comparison of glycemia values obtained from capillary blood and from venous plasma blood is a subject of extensive discussion [21-25]. However, it is known that the level of glucose in blood after a few hours of fasting varies according to the method employed for determination and the material used, i.e., capillary blood, venous blood, and serum/plasma or whole blood [26].

In a study on the validation of CG versus PG for the detection of DM and IGT, Kruijshoop et al. [22] detected a strong correlation between the two parameters both in the fasting condition $(r=0.92)$ and in the postprandial condition $(r=0.82)$, thus demonstrating the validity of the use of CG in the screening phase of epidemiological studies. In agreement with our results, the CG values detected by Kruijshoop et al. [22] were higher than PG values both for diabetic and normoglycemic or IGT subjects in the fasting condition.
(A)

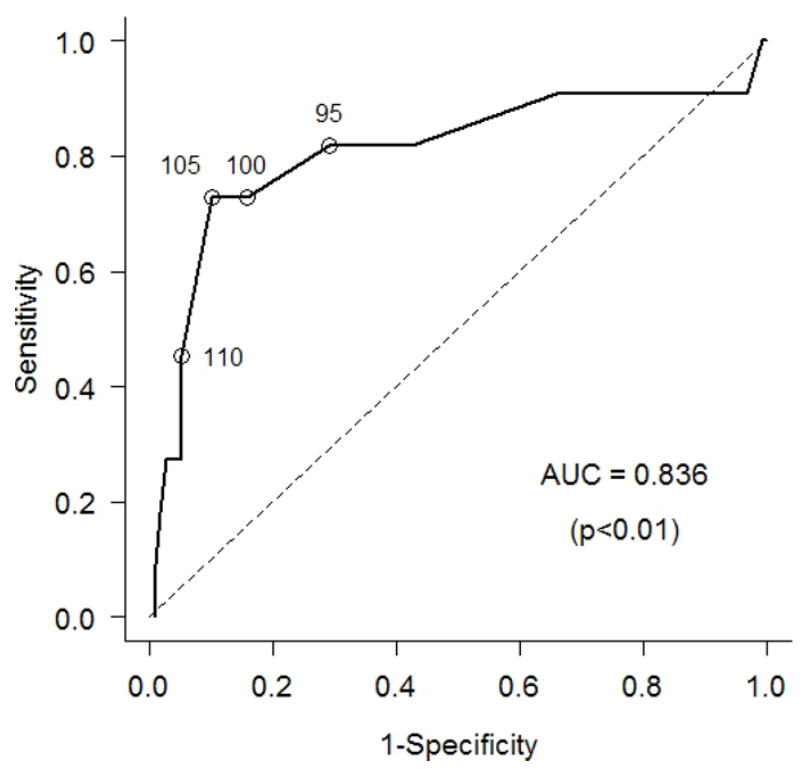

(B)

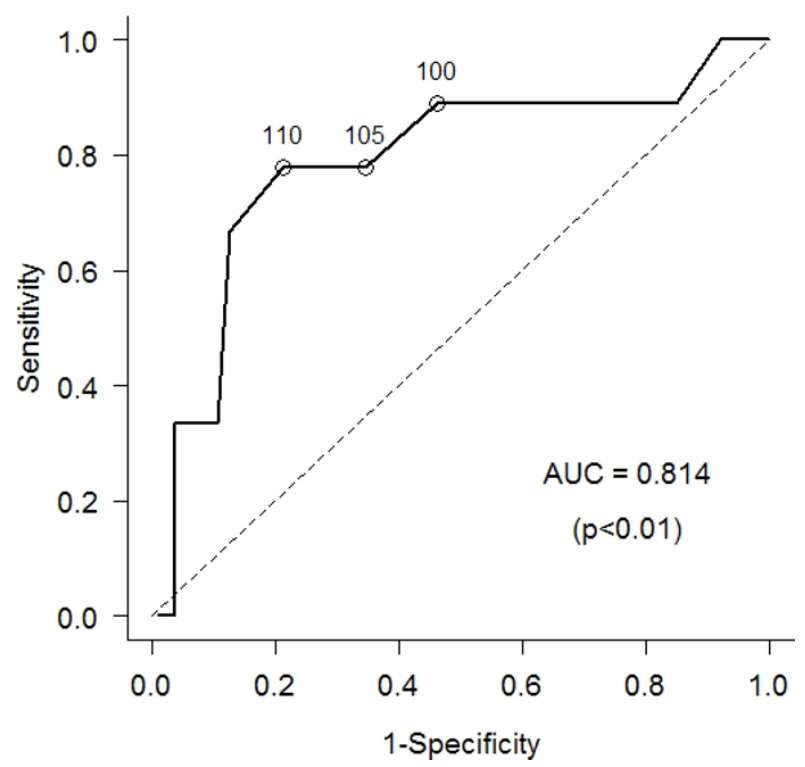

Figure 1 ROC curve for fasting PG (A) and CG (B) for the identification of DM in the Japanese-Brazilian population of Mombuca, Guatapará-SP, 2005 
Measurements made in plasma yield a 14 to $15 \%$ higher result compared to methods that use whole venous blood, which in turn yield about $5 \%$ lower glycemia results compared to capillary blood $[14,26]$. However, according to the WHO [16], under fasting conditions, plasma venous glycemia values are about $10 \%$ higher than CG values.

Analysis of the sensitivity and specificity of diagnostic tests by constructing the ROC curve has been recommended in epidemiological studies. In the present study, the cut-off points with the best specificity and sensitivity for CG and PG obtained on the basis of the ROC curve were $110 \mathrm{mg} / \mathrm{dl}$ and $105 \mathrm{mg} / \mathrm{dl}$, respectively. The areas under the curve for CG and PG were quite close, 0.814 and 0.836 , respectively, showing the expressive capacity of the tests in detecting DM. However, when the areas are superimposed, a separation of the 105 and $110 \mathrm{mg} /$ $\mathrm{dl}$ points is noted, suggesting that, even though the literature shows that PG values are higher than CG values, regarding the population studied here, PG values of 105 $\mathrm{mg} / \mathrm{dl}$ and CG values of $110 \mathrm{mg} / \mathrm{dl}$ should be used.

It is important to point out a limitation of this study for the proposed objectives by the number of participants, but the use of CG showed useful for decision taking immediately, i.e., to perform or not a 75 g glucose OGTT.

\section{Conclusions}

In conclusion, our data indicate that the cut-off points of $105 \mathrm{mg} / \mathrm{dl}(5.8 \mathrm{mmol} / \mathrm{l})$ and $110 \mathrm{mg} / \mathrm{dl}(6.1 \mathrm{mmol} / \mathrm{l})$ for PG and CG, respectively, are highly sensitive and specific for the diagnosis of DM2 and therefore would be appropriate for the screening of DM2 in this study population. It is important to give emphasis to the fact that the value recommended for CG is $5 \mathrm{mg} / \mathrm{dl}$ higher than that for PG, in contrast to WHO recommendations.

\footnotetext{
Acknowledgements

Research supported by Fundação de Apoio ao Ensino, Pesquisa e Assistência - Hospital das Clínicas, Faculdade de Medicina de Ribeirão Preto - USP. The authors wish to thank Associação Agro-Cultural e Esportiva de Guatapará for the support provided. We are grateful to Sebastião L. Brandão Filho for technical assistance and to E. Greene for English review of the manuscript.
}

\section{Author details}

'Departamento de Clinica Médica, Faculdade de Medicina de Ribeirão PretoUSP, (Av. Bandeirantes 3900), Ribeirão Preto-SP(14049-900), Brazil. ${ }^{2}$ Faculdade de Ciências Farmacêuticas de Ribeirão Preto-USP, (Av. Bandeirantes 3900), Ribeirão Preto-SP(14049-900), Brazil. ³ Departamento de Medicina Social, Faculdade de Medicina de Ribeirão Preto-USP, (Av. Bandeirantes 3900), Ribeirão Preto-SP(14049-900), Brazil. ${ }^{4}$ Escola de Enfermagem de Ribeirão Preto-USP, (Av. Bandeirantes 3900), Ribeirão Preto - SP (14040-902), Brazil.

\section{Authors' contributions}

MCFF, LJF and MCF participated in the design of the study. MCFF, RCGA, RCF, AEP, ALDF, LF and MCF performed the data collection. EM performed the statistical analysis. MCFF, RCGA, LJF and MCF wrote the paper. All authors read and approved the final manuscript.

\section{Competing interests}

The authors declare that they have no competing interests.

Received: 23 September 2009

Accepted: 22 January 2010 Published: 22 January 2010

\section{References}

1. King H, Aubert RE, Herman WH: Global burden of diabetes, 1995-2025: prevalence, numerical estimates, and projections. Diabetes Care 1998, 21:1414-1431.

2. Wild S, Roglicroglic G, Green A, Sicree R, King H: Global prevalence of diabetes. Estimates for the year 2000 and projections for 2030. Diabetes Care 2004, 27:1047-1053.

3. Brasil. Ministério da Saúde. Secretaria de Atenção à Saúde. Departamento de Atenção Básica: Diabetes Mellitus/Cadernos de Atenção Básica-no.16, Normas e Manuais Técnicos, Brasília-DF. 2006, 64.

4. American Diabetes Association: Economic costs of diabetes in the U.S. in 2002. Diabetes Care 2003, 26:917-932.

5. Fujimoto WY, Leonetti DL, Kinyoun JL, Newell-Morris LL, Shuman WP, Stolov WC, Whal PW: Prevalence of diabetes mellitus and impaired glucose tolerance among second generation Japanese American men. Diabetes 1987, 36:721-729.

6. Hara H, Equsa $G$, Yamakido $M$, Kawate R: The high prevalence of diabetes mellitus and hyperinsulinemia among the Japanese-Americans living in Hawaii and Los Angeles. Diabetes Res Clin Pract 1994, 24(Suppl):S37-S42.

7. Franco LJ, Gimeno SGA, Ferreira SRG, lunes M: Incremento na Mortalidade associada à presença de Diabetes Mellitus em nipo-brasileiros. Revista de Saúde Pública 1998, 32:118-124.

8. Gimeno SGA, Ferreira SRG, Franco L, Hirai AT, Matsumura RS, Moisés RS Prevalence and 7-year incidence of Type II diabetes mellitus in a Japanese-Brazilian population: an alarming public health problem. Diabetologia 2002, 45:1635-1638.

9. Malerbi DA, Franco LJ: Multicenter study of the prevalence of diabetes mellitus and impaired glucose tolerance in urban Brazilian population aged 30-69 years. Diabetes Care 1992, 15:1509-1516.

10. Grupo de Estudos de Diabetes na Comunidade Nipo-Brasileira (JBDSG): Diabetes Mellitus e Doenças Associadas em Nipo-Brasileiros São Paulo: Gree Forest do Brasil Editora 2004

11. UK Prospective Diabetes Study(UKPDS)Group: Intensive blood-glucose control with sulphonylureas or insulin compared with conventional treatment and risk of complications in patients with type 2 diabetes (UKPDS 33). Lancet 1998, 352:837-853.

12. Georg AE, Duncan BB, Toscano CM, Schmidt Ml, Mengue S, Duarte C, Polaczyk CA: Economic analysis of a screening program for diabetes mellitus in Brazil. Rev Saúde Pública 2005, 39:452-460.

13. American Diabetes Association: Standards of Medical Care in Diabetes. Diabetes Care 2008, 31(s1):S5-S11.

14. American Diabetes Association: Screening for Type 2 Diabetes. Diabetes Care 2003, 26(s1):S21-S24

15. Oliveira JEP, Milech A: Diabetes Mellitus-Clínica, Diagnóstico e Tratamento Multidisciplinar São Paulo: Editora Atheneu 2004.

16. Worldworld Health Organization: Definition, diagnosis and classification of diabetes mellitus and its complications. Report of WHO Consultation. Part 1: Diagnosis and Classification of Diabetes Mellitus. Genebra WHO 1999.

17. Pagano M, Gauvreau K: Princípios de Bioestatística. São Paulo: Thomson Learning 2006.

18. Delong ER, Delong DM, Clarke-Pearson DL: Comparing the areas under two or more correlated receiver operating characteristic curves: a non parametric approach. Biometrics 1988, 44:837-845.

19. Harris Ml, Eastman RC: Early detection of undiagnosed diabetes mellitus: a US perspective. Diabetes Metab Res Rev 2000, 16:230-236.

20. Engelgau MM, Narayan KMV, Herman WH: Screening for type 2 diabetes. Diabetes Care 2000, 23:1563-1580.

21. Colagiuri S, Sandbaek A, Carstensen B, Christensen J, Glumer C, Lauritzen T, Borch-Jonhsen K: Comparability of venous and capillary glucose measurements in blood. Diabetic Medicine 2003, 20:953-956. 
22. Kruijshoop M, Feskens EJM, Blaak EE, Bruin TWA: Validation of capillary glucose measurements to detect glucose intolerance or type 2 diabetes mellitus in the general population. Clinica Chimica Acta 2004, 341:33-40.

23. Kuwa K, Nakayama T, Hoshino T, Tominaga M: Relationships of glucose concentrations in capillary whole blood, venous whole blood and venous plasma. Clinica Chimica Acta 2001, 307:187-192.

24. Stahl M, Brandslund I, Jorgensen LG, Hyltoft Petersen P, Borch-Johnsen K, de Fine Olivarius N: Can capillary whole blood glucose and venous plasma glucose measurements be used interchangeably in diagnosis of diabetes mellitus?. Scand J Clin Lab Invest 2002, 62:159-166.

25. Stahl $\mathrm{M}$, Brandslund $\mathrm{I}$ : Measurement of glucose content in plasma from capillary blood in diagnosis of diabetes mellitus. Scand I Clin Lab Invest 2003, 63:431-440.

26. Arduino F: Sintomas, Diagnóstico, Prognóstico e Mortalidade do Diabetes. Diabetes Mellitus Rio de Janeiro: Editora Guanabara KooganArduino F, 3 1980, 78-94.

doi:10.1186/1758-5996-2-6

Cite this article as: Foss-Freitas et al: Comparison of venous plasma glycemia and capillary glycemia for the screening of type 2 diabetes mellitus in the Japanese-Brazilian community of Mombuca (GuataparáSP). Diabetology \& Metabolic Syndrome 2010 2:6.

Publish with BioMed Central and every scientist can read your work free of charge

"BioMed Central will be the most significant development for disseminating the results of biomedical research in our lifetime. "

Sir Paul Nurse, Cancer Research UK

Your research papers will be:

- available free of charge to the entire biomedical community

- peer reviewed and published immediately upon acceptance

- cited in PubMed and archived on PubMed Central

- yours - you keep the copyright 